\title{
GLOBALIZACJA W ŚWIETLE TEORII EKONOMII I TEORII ZARZĄDZANIA
}

\begin{abstract}
Streszczenie
W artykule podjęto próbę usystematyzowania poglądów na temat globalizacji dzięki wprowadzeniu kilku kryteriów porządkujących. Omówiono zatem poziomy globalizacji, takie jak: makroekonomiczny, mezoekonomiczny, mikroekonomiczny oraz gospodarstw domowych. Na tych różnych poziomach na temat globalizacji wypowiadali się przedstawiciele dyscyplin ekonomicznych: makroekonomii, finansów oraz teorii zarządzania, prezentując różne, niekiedy przeciwne, poglądy. Wśród nich opisano poglądy pozytywne, negatywne i umiarkowane na temat związane z globalizacją. Analizowano również wpływ globalizacji na kształtowanie się poglądów o strategii przedsiębiorstw.
\end{abstract}

Słowa kluczowe: globalizacja, teorie globalizacji, strategie globalizacji

\section{GLOBALISATION IN LIGHT OF THEORY OF ECONOMICS AND MANAGAMENT}

\section{Summary}

The paper attempts to systematise the diverse views on globalisation by introducing several classificatory criteria. The author discusses the levels of globalisation, e.g., macroeconomic, sectoral, microeconomic, and household levels. Presented are views expressed by macroeconomists, finance specialists, and management theorists. They represent different, sometimes contradictory, attitudes to globalisation and its effects: positive, negative or neutral. One of the chapters provides an analysis of the impact of globalisation on strategy theories.

Key words: globalisation, globalisation theories, globalisation strategies

\section{Wstęp}

Celem artykułu jest próba odpowiedzi na pytanie, dlaczego jest tak wiele odmiennych poglądów na temat procesu globalizacji, jak również próba usystematyzowania tej różnorodności poglądów przy pomocy kilku kryteriów porządkujących. Wskazano więc różne poziomy globalizacji, takie jak: makroekonomiczny, mezoekonomiczny, mikroekoekonomiczny, różnorodne pojmowanie globalizacji przez przedstawicieli

\footnotetext{
${ }^{1}$ Dr hab. J. Borowski, prof. UwB - Wydział Ekonomii i Zarządzania Uniwersytetu w Białymstoku; e-mail: j.borowski@uwb.edu pl.
} 
rozmaitych dyscyplin ekonomicznych czy wreszcie wielorakie nastawienie tych teoretyków do globalizacji. Zatem poddano analizie poglądy makroekonomistów na proces globalizacji, poglądy teoretyków zarządzania, a wśród nich podejście pozytywne, negatywne i umiarkowane. Oczywiście, omawiane poglądy są manifestowane przy pomocy różnych teorii globalizacji. Ich zwięzłe omówienie stało się również przedmiotem uwagi autora. Końcową część artykułu poświęcono analizie wpływu obecnego kryzysu na proces globalizacji.

\section{Poziomy globalizacji}

Zjawisko globalizacji , mimo upływu lat, wciąż inspiruje wiele pytań, w tym całkiem podstawowych, takich, jak: co to jest ? jak działa? jakie sa poglądy na temat skutków i przyszłości globalizacji? Pytania te naturalnie wymagaja kompetentnych odpowiedzi. Jednak nie jest to łatwe, skoro w latach 2000-2004 opublikowano pięć tysięcy książek na temat globalizacji, podczas gdy w latach dziewięćdziesiątych tylko pięćset [Ghemawat, 2007, s. 3]. Równocześnie pomiędzy 1995 a 2003 rokiem tempo wzrostu liczby tytułów o globalizacji podwajało się co 18 miesięcy, przekraczając tzw. prawo Moora na temat dynamiki rozwoju zjawiska.

Fakt zajmowania się tą problematyką częstokroć większej liczby badaczy z coraz większą intensywnością z pewnością świadczy o braku konsensusu pomiędzy autorami co do wszystkich niemal kluczowych problemów globalizacji. Przytoczone wyżej liczby publikacji stanowią usprawiedliwienie dla autora, że nie pretenduje do oferowania arbitralnych wyjaśnień. Niemniej jednak już choćby zgłoszenie poniższych uwag nieco przybliża nas do lepszego rozumienia tego zjawiska.

$\mathrm{Na}$ temat globalizacji ekonomicznej wypowiadały się trzy grupy uczonych, reprezentujących trzy dyscypliny ekonomiczne, takie jak:

- makroekonomia,

- zarządzanie i marketing,

- finanse i bankowość.

W tym ostatnim przypadku trzeba zauważyć, że nieraz w tych rozważaniach finanse państwa i bank centralny stanowią komponent rozważań makroekonomicznych, zaś finanse przedsiębiorstw i banki komercyjne, jako specyficzny rodzaj przedsiębiorstwa, są komponentem rozważań dotyczących obszaru zarządzania i marketingu. Natomiast niekiedy oddzielnie jest analizowane zjawisko globalizacji na światowym rynku finansowym. Rozważania tego typu szczególnie nasiliły się w ostatnich kilku latach w zwiazku ze skutkami światowego kryzysu finansowego i jego wpływem na gospodarkę realna. Mimo to, można stwierdzić, że w większości opracowań uwaga autorów koncentrowała się na dwóch polach badawczych: makroekonomicznym i zarządzania przedsiębiorstwami.

Autorzy prowadzacy badania nad globalizacją adresowali swoje rozważania nie tylko do wspomnianych, rozmaitych obszarów nauk ekonomicznych, lecz również do różnych poziomów globalizacji. Rozważania o poziomach globalizacji umożliwiają wyjaśnianie niejasności, a nawet chaosu, który towarzyszy dyskusji o globalizacji. 
W literaturze przedmiotu wyróżnia się trzy poziomy globalizacji, takie jak:

- poziom makroekonomiczny, który obejmuje rozważania na temat: procesów i skutków globalizacji zachodzących w skali gospodarki światowej, regionów geograficznych rozumianych jako kontynenty bądź grupy krajów na różnych kontynentach (kraje bogate i kraje wschodzące) czy wreszcie poszczególne państwa;

- $\quad$ poziom mezoekonomiczny, który obejmuje rozważania na temat zjawiska globalizacji zachodzącego na poziomie sektorów gospodarki (branż przemysłu i usług). Na przykład M. Porter już w 1980 roku zauważył specyfikę konkurencji w sektorach globalnych i rozproszonych [Porter, 1999, s. 270];

- poziom mikroekonomiczny, który obejmuje rozważania na temat udziału przedsiębiorstw w globalizacji i wpływu globalizacji na ich funkcjonowanie.

Jednakże, gdy rozpatruje się poziomy globalizacji z punktu widzenia czynników sprawczych - podmiotów kształtujących proces globalizacji, to należy mówić o dwóch decyzyjnych poziomach globalizacji, to jest makroekonomicznym, gdzie decyzje są podejmowane na szczeblu ponadrządowym (ugrupowania integracyjne bądź międzynarodowe organizacje gospodarcze, takie jak: UE, NAFTA, WTO, OECD) i rządowym, a także mikroekonomicznym - na szczeblu przedsiębiorstw.

Szczebel mezoekonomiczny - sektorowy jest tym poziomem, na którym można lepiej obserwować proces globalizacji, zwłaszcza jego wpływ na strategie przedsiębiorstw, ale nie można podejmować decyzji w tej sprawie, ponieważ nie istnieje podmiot decyzyjny. Znana jest na przykład analiza M. Portera na temat formowania się sektorów globalnych na rynku światowym i różnic w strategiach przedsiębiorstw działajacych w sektorach globalnych i nieglobalnych, która jest najwcześniejszą, historycznie teoretyczną, uwaga na temat globalizacji [Porter, 1999, s. 270].

W recenzji ksiązek: T. Friedmana, P. Ghemawata i B. Sethna opisano natomiast trzy, nieco inne, poziomy globalizacji:

- 1.0. globalizacja na poziomie kraju,

- 2.0. globalizacja na poziomie przedsiębiorstwa,

- 3.0. globalizacja na poziomie osób (gospodarstw domowych), co jest bardzo trafnym spostrzeżeniem [Sethna, 2008].

Bowiem jest oczywiste, że gospodarstwa domowe uczestniczą w globalizacji, pracując w sektorach eksportowych lub w firmach zagranicznych we własnym kraju oraz korzystają z rezultatów globalizacji, mając dostęp do relatywnie tanich produktów i usług o dobrej jakości pochodzących ze świata, choć sobie tego nie uświadamiaja, np. uczestnicząc w protestach przeciwko globalizacji.

Interesującym paradoksem jest także to, że pomimo wielkiej roli przedsiębiorstw w kształtowaniu i rozwoju globalizacji, makroekonomiści na ogół nie analizują wszechstronnie tego zjawiska i prowadzą rozważania niejako ponad tym czynnikiem sprawczym, często nadmiernie wyolbrzymiając zagrożenia ze strony korporacji transnarodowych wobec roli państwa w gospodarce.

Prowadzi to do błędnych ocen i wniosków związanych ze zjawiskiem globalizacji, a zwłaszcza jej przyszłością. O ile w pewnej fazie kryzysu finansowego makroekonomiści zaczęli zgłaszać obawy o groźbie powrotu do protekcjonizmu i zablokowa- 
niu globalizacji, to teoretycy zarządzania ani na chwilę nie wstrzymali badań nad strategiami globalnymi korporacji transnarodowych i sposobami polepszania konkurencyjności międzynarodowej krajów i przedsiębiorstw.

Oczywiście, przedsiębiorcy również nie przejmują się tymi ocenami i rozważaniami makroekonomistów i budują strategie oparte na założeniu rozwoju globalizacji (np.: Google, Microsoft, Apple, Cisco).

Wyodrębnienie nauk o zarządzaniu w latach sześćdziesiątych XX wieku, oprócz wielu pozytywnych skutków dla przedsiębiorstw, w następstwie prowadzi do rozdźwięku pomiędzy obydwoma kierunkami w kwestii zachowań przedsiębiorstw, czego efektem jest jednocześnie wiele nieporozumień w odniesieniu do analizy globalizacji [Rummelt, 1991, s. 5].

\section{Podstawy teoretyczne globalizacji}

Z powyższych rozważań wynika jasno, że nie istnieje jakaś spójna teoria globalizacji. Makroekonomiczny nurt pozytywny bazuje na: teorii wymiany międzynarodowej, teorii neoliberalnej ekonomii i teorii instytucjonalnej ekonomii. W odniesieniu do nurtu krytycznego jest użyteczna teoria neokeynesizmu, zaś globalizację przedsiębiorstw analizuje się na podstawie teorii zarządzania strategicznego. W ocenie globalizacji trudności nastręcza fakt, iż wśród autorów, wypowiadających się na ten temat, występują trzy postawy wobec tego zjawiska: pozytywna, krytyczna i umiarkowana.

\subsection{Podejścia w sprawie globalizacji w nauce ekonomii}

\section{Podejście pozytywne}

Smith i Ricardo, głosząc w swych dziełach idee wolności gospodarczej, otwartości gospodarki, a w szczególności ukazując korzyści z wymiany międzynarodowej jako źródło bogactwa narodowego, stworzyli fundamenty teorii kosztów komparatywnych, która przez ponad dwieście lat stanowiła obowiązująca doktrynę również dla polityki gospodarczej wielu państw. Jej głównym przesłaniem była zachęta do umiędzynarodowienia gospodarki, a więc do globalizacji w obecnym języku ekonomii.

We współczesnej makroekonomii pozytywne podejście reprezentują tacy uznani autorzy, jak: Jeffrey Sachs [Sachs, 1998], Jagdish Bhagwati [Bhagwati, 2004] Thomas Friedman [Friedman, 2005], P. Mason [Mason, 2001], M. Wolf [Wolf, 2005] czy J. Wilkin [Wilkin, 1997].

Spośród wymienionych autorów najwcześniej i w miarę syntetycznie globalizację scharakteryzował J. Sachs, który utożsamił ją z rosnąca liczbą i intensywnością powiązań krajów i firm w skali międzynarodowej. Wśród pięciu tysięcy definicji obecnie funkcjonujących wykorzystano tutaj definicję J. Wilkina. Definiując to zjawisko, J. Wilkin przyjąl, że: Globalizacja jest procesem rozszerzania i intensyfikacji wiezi: produkcyjnych, bandlowych, finansowych, informacyjnych pomiedsy podmiotami gospodarcsymi w skeali swiatowej. $W$ trakcie tego procesu nastepuje nie tylko zageszrzenie kontaktón, relacji i przeptywón, ale takize wrmoc- 
nienie sity wrajemnego oddziatywania podmiotón gospodarcsych w uktadzৃie swiatonym. Gospodarowanie, zarówno od strony zasilania w caynniki produkcji, jak i od strony efektów, jest coraz. silniej zdominowane globalnie [Wilkin, 1997].

Proces ten włącza się w cztery podstawowe nurty, które tworzą:

- przepływy handlu. Już od zakończenia drugiej wojny światowej obserwuje się zjawisko szybszego wzrostu tempa handlu światowego niż produkcji przemysłowej i GDP, co odzwierciedlało się w rosnącym udziale eksportu i importu w GDP niemal w każdym kraju uprzemysłowionym;

- $\quad$ przeplywy finansowe. W ciagu ostatniego ćwierćwiecza międzynarodowe przepływy strumieni kapitałowych rosły szybciej, niż handlu międzynarodowego, zaś inwestycje bezpośrednie jeszcze szybciej. W ten sposób materializuje się polityka wielkich korporacji międzynarodowych, które w poszukiwaniu popytu i tańszych kosztów produkcji błyskawicznie przenoszą się z jednego kraju do drugiego, traktując cały glob ziemski jako globalny rynek: kapitału, pracy, towarów i usług;

- $\quad$ przepływy produkcji. Procesom globalizacyjnym w sferze produkcji sprzyja niespotykana wcześniej łatwość przenoszenia różnych faz procesu produkcyjnego do obszarów o niższych kosztach wytwarzania. Omówione niżej czynniki, takie jak: liberalizacja, deregulacja i obniżanie kosztów transportu i komunikacji sprawiły, że w korporacji międzynarodowej łatwo jest wyróżnić i podzielić łańcuch wartości pomiędzy różne kraje;

- $\quad$ rosnąca sieć traktatów i innych powiązań instytucjonalnych [Sachs, 1998].

Procesowi globalizacji sprzyja z coraz większą siłą narastający zakres liberalizacyjnych zobowiązań zawartych w traktatach i umowach międzynarodowych, odnoszących się do: handlu, polityki inwestycji zagranicznych, podatków, praw własności przemysłowej, nadzoru bankowego, wymienialności walut, a nawet kontroli korupcji. Przykładowo można tu wspomnieć o: obejmującym 132 kraje porozumieniu G-77, regionalnych zobowiazaniach wynikających $z$ udziału w organizacjach integracyjnych (UE) $\mathrm{i}$ innych blokach handlowych (NAFTA) oraz umowach bilateralnych.

W literaturze przedmiotu wskazuje się równocześnie na decydującą rolę pewnych czynników sprzyjających rozwojowi zjawiska globalizacji, bez których proces ten nie mógłby zaistnieć. Wśród nich na czoło wysuwają się:

- liberalizacja gospodarek narodowych, ich otwieranie się na przepływy dóbr i usług, kapitału i pracy. Połączone siły teoretyków, wyznawców idei „niewidzialnej ręki rynku" i wolnego rynku oraz korporacji transnarodowych zainteresowanych w obalaniu barier protekcjonistycznych w końcu zwyciężyły w zmaganiach liberalizmu z protekcjonizmem trwajacych od 200 lat. Ogromne, praktyczne znaczenie ma fakt, iż idee liberalizacji gospodarczej głęboko zakorzeniły się $\mathrm{w}$ najważniejszych organizacjach międzynarodowych, takich jak: OECD, WTO, MFW i Bank Światowy. Ich efektywny wpływ jest taki, iż przyjęcie kraju do OECD lub WTO, jak również chęć uzyskania wsparcia finansowego ze strony MFW bądź Banku Światowego nieodwołalnie wiąże się z obowiązkiem prowadzenia liberalnej polityki gospodarczej i handlowej; 
- liberalizacja i deregulacja narodowych rynków finansowych. Proces znoszenia ograniczeń dewizowych, barier dla swobodnego przepływu kapitału, zakładania oddziałów i banków za granica stanowił odpowiedź systemu finansowego na globalizacyjne wyzwania ze strony handlu i produkcji oraz samoistnie pobudzał globalizację w sektorze finansowym;

- postęp techniczny w sferze transportu i innowacje w logistyce zblizyły kiedyś odległe geograficznie rejony świata i obniżyły koszty przemieszczania towarów;

- rewolucja informatyczna i telekomunikacyjna umożliwia szybki i tani przepływ informacji, tworzac dobre warunki procesu globalizacji w sferze usług, w tym zwłaszcza: finansowych, konsultingowych, informatycznych i marketingowych.

\section{Podejście krytyczne}

W nurcie makroekonomicznym globalizacji, obok zwolenników tego procesu, można również zauważyć dość licznych oponentów, którzy krytykuja globalizację. Uważają oni, że globalizacja jest złym procesem. Sądza, że działając pod dyktando wielkich korporacji, czemu nie sprzeciwiają się słabnące rządy, globalizacja niesie ze sobą: wiele nieszczęść gospodarczych, grabieżczą eksploatację zasobów, masowe bezrobocie, wyzyskiwanie pracy dzieci i kobiet, zagrożenie ekologiczne planety itp. Według nich, kolejne kryzysy zaś doprowadzą ponownie do protekcjonizmu.

Takie podejście krytyczne reprezentują wyznawcy teorii J. M. Keynesa, w tym zwłaszcza neokeynesiści. Jednym z najbardziej znanych krytyków globalizacji był, laureat nagrody Nobla i początkowo szef doradców prezydenta B. Clintona, J. E Stiglitz, który po dymisji ze stanowiska głównego ekonomisty Banku Światowego, napisał wysoce krytyczna, choć bardziej publicystyczną niż naukowa, książkę prezentującą negatywne przejawy i skutki globalizacji [Stiglitz, 2002].

Jednakże pod wpływem argumentów J. Bhagwati [Baghwati, 2004] zawartych w książce napisanej w obronie globalizacji, zjadliwej krytyki tygodnika „The Economist” [Accusing the IMF ..., 2002], jak również wnikliwych, głębokich studiów nad globalizacja, cztery lata później Stiglitz wycofał się z krytycznego stanowiska wobec globalizacji, publikując nową książkę, w której poparł ten proces i zgłosił szereg propozycji jego doskonalenia [Stiglitz 2006]. Jednakże, pamiętając o destrukcyjnych skutkach jego poprzedniej książki, w „The Economist” napisano tym razem przychylniejsza, ale nadal cierpką recenzję. Zauważono, że nie jest to zła książka o globalizacji, lecz bywają lepsze i oryginalniejsze (np. wspomnianego J. Bhagwati), kończąc stwierdzeniem, że jeśli wielki i oryginalmy teoretyk spedza czas, piszac jeszzze jedna, podobna do innych ksiazke o globalizacji, potwierdza tylko swój wtasny poglad, że rynki crasem btednie alokuja zasoby [A Nobel..., 2006].

Spośród polskich ekonomistów wytrwałym przeciwnikiem globalizacji jest W. Szymański, który napisał co najmniej trzy książki na ten temat.

Fala krytyki wobec globalizacji podniosła się po wybuchu kryzysu finansowego w 2007 roku, przynosząc wiele dowodów na wadliwe działanie globalnych rynków finansowych oraz wiele, niekiedy bardzo radykalnych, projektów ich regulacji. W związ- 
ku ze specyfiką zjawiska globalizacji w sferze finansów pominięto ich omówienie, ograniczając się tylko do krótkiego komentarza. Odpowiadając na pytanie, dlaczego tak trudno jest zrozumieć skutki globalizacji na rynku finansowym i przeciwdziałać negatywnym skutkom, można wskazać następujące fakty.

Rynek finansowy jest wysoce skomplikowany, złożony z wielu rynków o różnych i złożonych produktach, które na dodatek nieustannie się zmieniaja, podlegają innowacjom w ramach tzw. inżynierii finansowej. Nadzór finansowy, który ma pilnować bezpieczeństwa klientów tego rynku, nie jest w stanie nadążyć za innowacjami produktowymi finansistów w bankach, bowiem na wprowadzane regulacje odpowiadają oni jeszcze bardziej sofistycznymi instrumentami

Istnieje wiele stopni wtajemniczenia, opartych na różnych poziomach agregacji instrumentów finansowych (produktów). Stąd też łatwo o nieporozumienia pomiędzy analitykami, którzy w trakcie dyskusji muszą ustalić istotę rzeczy.

Warto przypomnieć, że jedną z trudności jest odmienne, niż w klasycznej teorii, zachowanie popytu w reakcji na zmianę cen. Na rynku towarów i usług popyt zmniejsza się w miarę wzrostu ceny, zaś na rynku finansowym popyt rośnie w miarę wzrostu cen! Siły rynku nie mogą tu wystapić w roli regulatora prowadzącego do równowagi, dlatego otwiera się pole do niekontrolowanej spekulacji i drastycznych skutków gospodarczych, przy nieodpowiedzialnym podejściu do oceny ryzyka finansowego (moral hazard).

\section{Zarządzanie strategiczne o globalizacji}

\subsection{Podejście pozytywne do globalizacji}

W odróżnieniu od wielu teoretyków ekonomii, badacze zarządzania mają na ogół pozytywny stosunek do globalizacji, ponieważ wiedza, że zaostrzanie konkurencji zmusza przedsiębiorstwa do większej innowacyjności i zwiększania skali działania, co odbywa się z korzyścią dla klientów i utalentowanych przedsiębiorców. Cieszą się również dlatego, że globalizacja tworzy większy rynek na ich produkty (nowe strategie) i usługi (studia MBA i konsulting).

W porównaniu z teoretykami zarządzania makroekonomiści stosunkowo późno zaczęli zajmować się teoretyczną analizą zjawiska globalizacji, gdyż dopiero pod koniec lat dziewięćdziesiątych i na początku XXI wieku. Tymczasem teoretycy zarządzania i marketingu zauważyli to zjawisko dużo wcześniej, analizując międzynarodową działalność korporacji transnarodowych w skali globalnej.

Najwcześniej tę działalność poddał analizie naukowej M. Porter. W 1980 roku opublikował głośną książkę, która odtąd stała się kanonem nauki o zarządzaniu strategicznym [Porter, 1980]. W rozdziale poświęconym sektorowi globalnemu w sposób naukowy opisał specyfikę konkurowania w sektorach globalnych i sposoby osiagania przewagi konkurencyjnej przez firmy globalne, tj. takie, których sytuacja konkurencyjna na różnych rynkach lokalnych zależy nie tylko od konkurentów lokalnych, lecz od ich ogólnej sytuacji w skali światowej. Prostym testem na odróżnienie firmy globalnej od 
międzynarodowej jest analiza łańcucha wartości każdej z nich. Firma międzynarodowa stosuje odmienną strategię w każdym kraju i odpowiedni lokalny łańcuch wartości, zaś firma globalna stosuje strategię globalna, wykorzystując przewagi konkurencyjne w różnych krajach dzięki fragmentaryzacji łańcucha wartości i lokowaniu rozmaitych działań tworzących łańcuch wartości w różnych krajach.

Innym, ważnym teoretykiem $\mathrm{w}$ tym nurcie, któremu przypisuje się autorstwo terminu globalizacja, był Theodore Levitt, podobnie jak M. Porter, profesor Harvard Business School. Sławę zyskał dzięki artykułowi pt.: Krótkowsroczność marketingu (Marketing Myopia), który ukazał się w Harvard Business Review w 1960 roku. Artykuł traktuje się jako przełomowy dla powstania nowoczesnego marketingu. Levitt opisał liczne przykłady krótkowzroczności działań marketingowych, ograniczonych charakterystyką produktu i sugerował redefiniowanie rynku przedsiębiorstwa jako obszaru zaspokajania potrzeb klientów, powołując się na zbyt wąska, jego zdaniem, misję kolei amerykańskich, które nie zauważyły konkurencji ze strony transportu drogowego i lotniczego, a w porę nie dokonały reorientacji kluczowego biznesu.

Dopiero po czterdziestu latach M. Porter, już po odkryciu łańcucha wartości, zauważył błędność rozumowania Levitta, dowodząc, że dołączenie lotnictwa i transportu drogowego do kolejnictwa przyspieszyłoby tylko upadek wspomnianej firmy kolejowej z uwagi na różne łańcuchy wartości w każdym biznesie i brak synergii.

W 1983 roku Levitt opublikował głośny artykuł pt:: Globalization of Markets, w którym stwierdził, że wskutek rozwoju i dyfuzji technologii oraz masowej komunikacji, rynki globalne dążą do ujednolicenia, ponieważ ludzie wszędzie pragną tych samych produktów².

To stwierdzenie otworzyło pole do rozważań na temat nieograniczonych możliwości standaryzacji produkcji, co ułatwia firmom produkowanie produktów o podobnej technologii po niskich kosztach i dostarczanie ich po niskich cenach.

Modelowa, nieoparta na badaniach, a na dedukcji, koncepcja T. Levitta uzyskała dwadzieścia dwa lata później szczególne wsparcie w postaci głośnej ksiaż̇i T. Friedmana, wybitnego publicysty ekonomicznego „The New York Times”, trzykrotnego laureata nagrody Pulitzera, pt.: The World Is Flat. Książka ta została uznana przez Financial Times i Goldman Sachs za Biznesową Książkę Roku [Friedman, 2005]. Na podstawie analizy dziesięciu czynników działających konwergencyjnie na gospodarkę światowa, które autor nazwał flatteners - niwelujących różnice pomiędzy krajami, autor doszedł do wniosku, że gospodarka światowa zmierza w kierunku, opisanym przez T. Levitta, ujednolicania gustów, preferencji konsumentów i standaryzacji działań producentów.

Wśród tych dziesięciu czynników wymienił np.: dołączenie do gospodarki rynkowej krajów postkomunistycznych oraz Chin i Indii, ekspansję Internetu i innych mediów ułatwiających masową komunikację, outsourcing. Do tych czynników zaliczył następne dwa, zmierzające przede wszystkim w kierunku konwergencji.

Jednym z nich była zmiana modelu biznesowego relacji przedsiębiorstw ze współpracy pionowej na pozioma. Uzasadnił to faktem, że na przykład innowacje nie prze-

2 Ang.: Becouse of technology and communications advances global markets are becoming homogenized. People everywhere want the same things [Levitt, 1983]. 
pływają obecnie z góry w dół, lecz poziomo, pomiędzy firmami, ponieważ firmy współpracują ze sobą, aby stworzyć więcej wartości dla klienta [Steinhilber, 2008].

Drugim było wejście na światowy rynek pracy i konsumpcji 3 mld ludzi uczestniczących dzięki globalizacji w procesie wymiany dóbr i usług. Wymienione trzy główne czynniki nazwał terminem Triple Convergence - trzyczęściową konwergencją.

Interesujące jest to, w jaki sposób rodził się pomysł na elektryzujący uwagę opinii publicznej tytuł książki - Świat jest płaski. Podczas wizyty w Indiach autor prowadził dyskusję z prezesem zarządu Infosys, Nandanem Nilekiem, podczas której Nilek zauważył, że obecnie świat jest polem gry rynkowej, na którym wszyscy mają równe szanse wygrywać w konkurencji. Za przykład podał swą hinduską firmę, która stała się światowym graczem w globalnym sektorze wysokich technologii informatycznych, stwierdzając w pewnym momencie: Tom, The playing field is beeing levelled (Pole gry staje sie wyrómnane).

Podczas powrotnej drogi T. Friedman, próbując zrozumieć swojego rozmówcę przetłumaczył sobie jego słowa na prostsza frazę: The playing field is beeing flattened (Pole gry staje sie coraz bardziej plaskie). Flattened? Mój Boże! On mi powiedział, ze swiat jest plaski. Mam tytut do swojej ksiaziki!

Podsumowując pozytywne, a nawet entuzjastyczne stanowisko teoretyków zarządzania wobec globalizacji, można uznać, że według nich globalizacja uosabia najlepszy kierunek rozwoju świata. Dynamika rozwoju globalizacji jest bardzo wysoka, co znamionuje, że większość krajów będzie zglobalizowana. Przypomina to nieco podobne, entuzjastyczne podejście do euromarketingu w latach dziewięćdziesiątych ubiegłego wieku. Pojawily się wtedy naiwne poglądy o dominacji euromarketingu w ramach Unii Europejskiej, nie biorące pod uwagę wielkiego zróżnicowania w postawach i kondycji ekonomicznej konsumentów w różnych krajach [Sznajder, 1999; Komor, 2000].

\subsection{Podejście wstrzemięźliwe do globalizacji}

Zarówno teza T. Levitta, jak i zwłaszcza prowokacyjny tytuł książki Friedmana wywołały zdecydowana, choć wysoce kulturalna, reakcję innego, wybitnego teoretyka zarządzania, Pankaja Ghemawata, ucznia M. Portera i w swoim czasie najmłodszego w historii profesora Harvardu. Ghemawat od dłuższego czasu pracował nad zagadnieniem globalizacji i strategiami przedsiębiorstw na rynku globalnym, czemu dawał wyraz w publikacjach artykułów na ten temat. Badania P. Ghemawata, których wyniki sa publikowane od 2001 roku, podważyły przekonanie o sile tej tendencji [Ghemawat, 2007].

Przyjęcie przez T. Levitta założenia, że postęp technologii i komunikacji międzyludzkiej prowadzi do ujednolicenia preferencji konsumentów i homogenizacji globalnych rynków towarowych oznacza, że myśl strategiczna zmierza w prostej linii do zwycięstwa standaryzacji nad adaptacja jako metodą produkcji i sprzedaży. Ostatecznym efektem byłby wtedy zanik strategii międzynarodowych przedsiębiorstw i wprowadzenie uniwersalnych strategii globalnych, zaadresowanych w ujednolicony sposób do wszystkich konsumentów na kuli ziemskiej. 
Po głośnym sukcesie książi T. Friedmana, potwierdzającej już w tytule tę apokaliptyczną dla konsumentów wizję globalizacji, P. Ghemawat podjął podbudowaną naukowo próbę weryfikacji tej teorii. Dowiódł, że fakty nie potwierdzają wiary obu autorów w zanik zróżnicowania gustów i rynków. Natomiast pokazują, że ogromna większość aktywności gospodarczej, prowadzona równocześnie w kraju i za granica, ma charakter lokalny, a nie międzynarodowy i nic nie wskazuje na to, aby szybko miało się to zmienić. Swe przekonanie zilustrował na tablicy, na której pokazał dziewięć rodzajów ludzkiej aktywności, gdzie udział komponentu międzynarodowego w większości nie przekroczył dziesięciu procent, zaś w jednym przypadku, handlu zagranicznego, sięgnął blisko trzydziestu procent ${ }^{3}$.

\section{Poziom globalizacji}

TABELA 1.

\begin{tabular}{|l|c|}
\hline \multicolumn{1}{|c|}{ Rodzaje aktywności } & $\begin{array}{c}\text { Udział aktywności mię- } \\
\text { dzynarodowej (w \%) }\end{array}$ \\
\hline Rozmowy telefoniczne & 3 \\
Imigracja & 4 \\
Studenci & 5 \\
Prace badawcze w dziedzinie zarządzania & 7 \\
Bezpośrednie inwestycje zagraniczne /inwestycje ogółem & 9 \\
Ruch turystyczny & 10 \\
Patenty & 14 \\
Zagraniczni inwestorzy na giełdach USA & 14 \\
Handel zagraniczny/GDP & 30 \\
\hline
\end{tabular}

Źródło: [Ghemawat, 2007, s. 4].

Wyjaśniając to zjawisko, P. Ghemawat wskazał rolę odległości nadal kluczową dla współpracy międzynarodowej. Twierdził, że teoretycy i menedżerowie nadmiernie uwierzyli w zanik odległości, jako bariery we współpracy międzynarodowej, przyjmując jako oczywistość, że siły globalizacji łatwo przezwyciężają tę barierę. Przez pojęcie odległości rozumiał przy tym nie tylko odległość geograficzną, lecz również różnice: kulturowe, administracyjne i ekonomiczne pomiędzy różnymi krajami. Wszystkie te różnice ujął w postaci modelu różnic, który nazwał CAGE (Culture, Administration, Geography, Economy). Zarówno we wspomnianym artykule z 2001 roku, jak i późniejszej ksiazżce [Ghemawat, 2007] dogłębnie wyjaśnił, jakie czynniki zróżnicowania i dlaczego stawiają mocny opór, a w niektórych przypadkach wręcz trwały opór globalistycznej tendencji ujednolicającej ludzkie postawy i zachowania. W tablicy 2. przedstawiono główne składniki zróżnicowania krajów w każdej z omawianych czterech kategorii, które powinny być brane pod uwagę przy podejmowaniu decyzji o internacjonalizacji działalności firmy.

\footnotetext{
${ }^{3}$ Liczba ta jest zawyżona w stosunku do rzeczywistych efektów kooperacji międzynarodowych, ponieważ międzynarodowy obrót podzespołami, częściami itp. jest liczony podwójnie, przy obrocie międzynarodowymi produktami gotowymi (samochody, sprzęt komputerowy itp.).
} 
Ghemawat twierdzil, iż menedżerowie nie doceniaja prawdziwych kosztów i rozmiarów ryzyka towarzyszących decyzji o wejściu na rynek obcy, co ujemnie wpływa na wyniki finansowe. Posługuja się tradycyjnymi metodami oceny atrakcyjności rynku obcego, stosując najczęściej metodę CPA - Country Portfolio Analysis, obejmująca analizę zamożności kraju oraz skłonność do konsumpcji. Okazuje się to dalece niewystarczające i często zawodne, o czym świadczą nieudane wejścia i wyniki badań dotyczących wpływu różnych czynników odległości na rozmiary obrotów handlu zagranicznego.

\section{Model CAGE}

\begin{tabular}{|c|c|c|c|c|}
\hline & $\begin{array}{l}\text { Odległość kul- } \\
\text { turowa }\end{array}$ & $\begin{array}{l}\text { Odległość ad- } \\
\text { ministracyjina }\end{array}$ & $\begin{array}{c}\text { Odległość } \\
\text { geograficzna }\end{array}$ & Odległość ekonomiczna \\
\hline $\begin{array}{l}\text { Kraje, } \\
\text { współpra- } \\
\text { ca bilate- } \\
\text { ralna }\end{array}$ & $\begin{array}{l}\text { Odmienność: ję- } \\
\text { zykowa, etnicz- } \\
\text { na, religijna } \\
\text { Brak wierzeń } \\
\text { Pod względem } \\
\text { wyznawanych } \\
\text { wartości, norm } \\
\text { moralnych }\end{array}$ & $\begin{array}{l}\text { Brak więzi kolo- } \\
\text { nialnych } \\
\text { Brak ugrupowań } \\
\text { integracyjnych } \\
\text { Brak wspólnej } \\
\text { waluty } \\
\text { Polityczna wro- } \\
\text { gość }\end{array}$ & $\begin{array}{l}\text { Odległość geo- } \\
\text { graficzna } \\
\text { Brak wspólnej } \\
\text { granicy } \\
\text { Różne strefy } \\
\text { czasowe } \\
\text { Różnice klima- } \\
\text { tyczne i różne } \\
\text { strefy zdro- } \\
\text { wotne }\end{array}$ & $\begin{array}{l}\text { Różnice pod względem za- } \\
\text { możności - GDP per capita } \\
\text { Różnice w kosztach i jakości: } \\
\begin{aligned} &-\quad \text { zasobów natural- } \\
& \text { nych } \\
&- \text { finansów } \\
&- \text { kapitału ludzkie- } \\
& \text { go } \\
& \text { infrastruktury }\end{aligned} \\
\text { Dostępność } \\
\text { informacji i wiedzy }\end{array}$ \\
\hline $\begin{array}{l}\text { Kraje, } \\
\text { wspól- } \\
\text { praca } \\
\text { wielo- } \\
\text { stronna }\end{array}$ & $\begin{array}{l}\text { Izolacjonizm } \\
\text { Tradycjonalizm }\end{array}$ & $\begin{array}{l}\text { Niedoskonałość } \\
\text { rynku } \\
\text { Autarkizm gospo- } \\
\text { darki } \\
\text { Poziom lokalnych } \\
\text { uprzedzeń } \\
\text { Brak udziału } \\
\text { w organizacjach } \\
\text { międzynarodo- } \\
\text { wych } \\
\text { Słabe instytucje, } \\
\text { korupcja }\end{array}$ & $\begin{array}{l}\text { Brak dostępu } \\
\text { do morza } \\
\text { Słaba infra- } \\
\text { struktura trans- } \\
\text { portowa } \\
\text { Rozmiary kraju } \\
\text { Odległość od } \\
\text { centrów gospo- } \\
\text { darczych }\end{array}$ & $\begin{array}{l}\text { Rozmiary gospodarki } \\
\text { Niski dochód na głowę }\end{array}$ \\
\hline
\end{tabular}

Źródło: [Ghemawat, 2007, s. 9]. 


\subsection{Podejście społeczno-ekonomiczne do globalizacji G. Sormana}

Globalizacji nie należy traktować wyłącznie jako części otoczenia przedsiębiorstwa i omawiać tak, jak omawia się otoczenie: ekonomiczne, społeczne, polityczne, techniczne itp. w tradycyjnych podręcznikach marketingu. Natomiast trzeba przyjąć, że jest to proces aktywnie, codziennie wpływający na warunki działania gospodarstw domowych i przedsiębiorstw na całym świecie.

Sorman określa globalizację jako jedną z najpotężniejszych, pozytywnych sił w historii ludności, prowadzących do redefinicji naszej cywilizacji. Twierdzi, że globalizację charakteryzuje sześć kategorii, do których należą: rozwój gospodarczy, demokracja, bogactwo kulturowe, normy polityczne i kulturowe, informacja i internacjonalizacja rządów prawa [Sorman, 2008]. Nie rozwijając szczegółowo jego rozważań w tej mierze, warto jedynie wskazać skutki wpływu globalizacji w niektórych obszarach.

W sferze ekonomicznej rzecz dotyczy nie tylko wzmożonej wymiany: towarów, usług, kapitału i pracy dzięki liberalizacji i deregulacji rynków. Najważniejszy jest efekt konwergencji wielu krajów do poszerzanego stale poziomu zamożności. Dzięki temu w ciagu ostatnich trzydziestu lat $800 \mathrm{mln}$ ludzi wyrwało się ze strefy ubóstwa i dołączyło do świata cywilizowanego, zasilając szeregi konsumentów oferty przemysłowej. Szacuje się, że w najbliższym dziesięcioleciu około 600 milionów ludzi z tych krajów będzie dysponować funduszem swobodnej decyzji, dającym im dostęp do dóbr konsumpcyjnych wyższego rzędu.

W obszarze demokracji niemal nikt dziś nie kwestionuje walorów demokracji, jako najlepszego systemu politycznego, zaś groźba międzynarodowych, zbrojnych konfliktów i wojen ulega zmniejszeniu, w miarę jak coraz więcej autokratycznych systemów przechodzi na stronę demokracji.

Globalizacja przyczynia się do poszerzania zasięgu norm kulturowych i politycznych, chroniących prawa obywatelskie kobiet oraz mniejszości społecznych i narodowych. Wystarczy wskazać dwa spektakularne przypadki: Chin, w których wzrósł ogromnie zakres swobody osobistej, oprócz politycznej, a także Indii, gdzie polityczne i pracownicze prawa kobiet i kasty nietykalnych uległy znacznemu poszerzeniu.

Z rozważań Sormana i wielu innych autorów wynika przekonanie o silnym, pozytywnym wpływie globalizacji na społeczeństwo i gospodarkę. Z punktu widzenia zarządzania i marketingu międzynarodowego istotne jest, że dzięki spowodowanemu przez globalizację wzrostowi gospodarczemu w krajach wschodzących ma miejsce polepszanie sytuacji materialnej milionów ludzi w tych krajach, wyrwanie ich z ubóstwa i umożliwienie dostępu do coraz szerszej gamy dóbr konsumpcyjnych, w dużej mierze importowanych lub produkowanych lokalnie na podstawie najnowszych technologii zagranicznych.

Istotne jest również wzbogacanie kulturowe poprzez upowszechnianie: wzorców racjonalnych zachowań konsumpcyjnych, standardów higieny, diety, spędzania wolnego czasu i ochrony środowiska. Po stronie popytu prowadzi to do ujednolicania zachowań konsumpcyjnych i wzorców konsumpcji w niektórych jej obszarach, takich jak: paczkowane towary konsumpcyjne (asortyment Nestle, Procter\&Gamble, Unilever), elektroniczny sprzęt użytkowy, elektroniczny sprzęt gospodarstwa domowego (biała 
technika kuchenna), urządzenie mieszkań (IKEA). Po stronie podaży umożliwia to rozszerzanie zakresu standaryzacji produkcji i marketingu, głównie w sferze dystrybucji (światowe sieci detaliczne) oraz promocji, zwłaszcza reklamy.

\section{Podsumowanie}

Udzielając odpowiedzi na pytanie o przyczyny obfitości i różnorodności poglądów na temat globalizacji i jej efektów, autor poddał analizie różne podejścia do globalizacji naukowców piszących na ten temat, w zależności od tego, którym poziomem globalizacji zajmowali się, tj.: makroekonomicznym, mezoekonomicznym, mikroekonomicznym.

Istotne różnice pojawiały się w szczególności wówczas, gdy o globalizacji pisali teoretycy ekonomii bądź zarządzania oraz jaki mieli emocjonalny stosunek do tego zjawiska, tj. pozytywny, negatywny czy wstrzemięźliwy. W odniesieniu do teorii zarządzania strategicznego autor opisał wpływ globalizacji na niektóre teorie, wskazując ich specyfikę globalizacyjna.

\section{Literatura}

Accusing the IMF Bad Faith 2002, The Economist June 6 th, dokument elektroniczny, tryb dostępu: [www.Economist.com/highliths/global, data wejścia: 15.10.2015]. Adolph G., Pettit J. 2008 The Rise of the New Blue Chips, „Strategy + Business”, Issue 52. A bigger world 2008, "The Economist", September 20th. A hopeful continent 2013, "The Economist" March 2nd.

A Nobel prize winner who remains an artist of the impossible 2006, „The Economist”, September $7^{\text {th }}$, dokument elektroniczny, tryb dostępu: [www.economist.com/highliths/ global, data wejścia: 16.10.2015].

Bhagwati J. N. 2004 In Defence of Globalisation, Oxford University Press, Oxford.

Bocian A. 2009 Procesy globalizaciji a krysys światowy, [w:] Od wielkiego kryzysu gospodarczego do wielkiego kryyysu finansowego. Perturbacje w gospodarce swiatowej w latach 1929-2009, J. Kaliński, M. Zalesko (red.), Wydawnictwo Uniwersytetu w Białymstoku, Białystok.

Borowski J. 2008 Globalizacja, konkurencyjność miedzynarodowa i strategie pržedsiebiorstw, Wydawnictwo Uniwersytetu w Białymstoku, Białystok.

Frankel J., Rose A. 2000 An Estimate of the Effects of Currency Union on Growth, Unpublished Working Paper, May.

Free trade cross Atlantic. Come on TTIP 2013, „The Economist”, February 16.

Friedman T. 2005 The World Is Flat, New York Farrar, Straus and Giraux.

Ghemawat G. 2001 Distance Still Matters, Harvard Business Review, September.

Ghemawat P. 2007 Redefining Global Strategy. Crossing Borders Where Differences Still Matter, Harvard Business School Press, Boston, Massachusets.

Kleinert A. 2008 Pankaj Ghemawat: The Thought Leader Interview, „Strategy+Business”, 26 may. 
Komor M. 2000 Euromarketing, Wydawnictwo Naukowe PWN, Warszawa.

Levitt T. 1983 Globalisation of Markets, „Harvard Business Review”, maj - czerwiec.

Porter M. 1980 Competitive Strategy.Techniques for Analysing Industries and Competitors, The Free Press, New York.

Roubini N. S., Mihm M. 2010 Crisis Economics: A Crash Course in the Future of Finance, The Penguin Press, New York.

Rumelt R.P., Schendel D., Teece D. 1991 Strategic Management and Economics, "Strategic Management Journal", 12.

Sachs J. 1998 Unlocking the Mysteries of Globalisation, „Foreign Policy”, Spring.

Sethna B. 2008 Ghemawat v Friedman Is the World Flat, „Decision Line” , From the Bookshelf, vol. 39 (4), dokument elektroniczny, tryb dostępu: [www.decisionsciences.org /DecisionLine/, data wejścia: 19.10.2015].

Sorman G. 2008 Globalisation is making the world a better place, [in:] 2008 Index of Economic Freedom, The Heritage Foundation and Dow Jones\& Company Inc.

State capitalism Special report 2012, „The Economist”, 21.

Steinhilber S. 2008 Strategic Alliances. Three Ways To Make Them Work, Harward Business Press Boston, Massachusets.

Stiglitz J. E. 2002 Globalisation and Its Discontents, Norton\&Company, New York, London.

Stiglitz J. E. 2006 Making Globalization Work, Norton\&Company, New York, London.

Sznajder A. 1999 Euromarketing, Wydawnictwo Naukowe PWN, Warszawa.

Szymański W. 2004 Interesy i sprzeczności globalizacji, Wydawnictwo Difin, Warszawa.

The World turned upside down 2010, „The Economist”, April, 15.

The gated globe, Special report 2013, "The Economist”, October 12 th.

Winning the $\$ 30$ trillion decathlon: Going for gold in emerging markets 2012, McKinsey Quarterly, August.

World GDP 2013, „The Economist”, December, 21.

World Investment Report 2005, UNCTAD, Geneva.

World Investment Report 2006, UNCTAD, Geneva.

World Investment Report 2011, UNCTAD, Geneva.

World Investment Report 2012, UNCTAD, Geneva.

World Investment Report 2013, UNCTAD, Geneva. 